\title{
EESTI KOHAMURRETE OLUKORD VIIMASE RAHVALOENDUSE PEEGLIS
}

\author{
SIIM ANTSO, KADRI KOREINIK, KARL PAJUSALU
}

$\mathrm{E}$ estis nagu mujalgi on keelelise variatiivsuse teisenemisega seotud kaks mastaapset ühiskondlikku muutust: linnastumine ja üldisemalt moderniseerimine, mis on väljendunud industrialiseerimises, ühiskondliku ja majandusliku lõimituse kasvus, rahvusriigi loomises, riigihalduse tekkes, üldharidussüsteemi juurutamises ühtluskooli põhimõttel, massimeedia levikus ning ka normikeele kehtestamises ja riikliku keelekorralduse rakendamises. Linnastumise kui mitmejärgulise protsessi kohta on üldiselt teada, et juba XIX sajandi jooksul hakkas perifeeriate elanikkond tasapisi koonduma keskustesse (ka eeslinnadesse) ja hiljem XX sajandi lõpu poole hajuma ka keskuste tagamaadele. Peab siiski mainima, et Nõukogude ideoloogiad ja poliitikad (nt tööhõive tsentraalne planeerimine, elamumajandus) pidurdasid üldist protsessi ning põhjustasid alalinnastumist, kuigi esines piirkondlikke erinevusi (vt nt Sjoberg, Tammaru 1999; Tammaru 2001).

Selles kontekstis on kohamurrete taandumist kirjeldanud mitme põlvkonna keeleteadlased. Näiteks juba XIX sajandi keskel on F. J. Wiedemann (2002 [1864]: 11) arvanud, et Võru murre „tulevikus Tallinna murde [põhjaeesti kirjakeele] ees veel enam taandub". Peaaegu sajand hiljem võtab Andrus Saareste (2006 [1952]: 122) XIX ja XX sajandi muutused kokku järgmiselt: „...nüüdsest peale, koos talurahva pärisorjusest ja sunnismaisusest vabanemisega, eri maaosadest põlvneva elanikkonna kasvamisega linnades, kooliõpetuse tõhustumisega ja avaliku kirjasõna avardumisega ning selle mõju paisumisega sugeneb jagunemise ja lagunemise liikumisele vastukaaluks üh in emist ja tas andumist...."

1960. aastatel iseloomustab Ülo Parbus (1966: 8) murdekeele ja kirjakeele vahekorda terminiga siirdekeel: murrakute erinevused taanduvad kirjakeele ees, kuid piirkondlike eripäradeta ühtne, normeeritud keelekuju pole veel täielikult välja kujunenud. Tema käsitlus kannab hinnangut, mille järgi „kirjakeelsete normide võit murde- või ka siirdekeelsete üle on ette määratud" (Parbus 1966: 11). Parbuse seisukohta, mille järgi just murraku primaarsed tunnused kaovad kiiremini kui sekundaarsed, laiemale piirkonnale omased jooned (Parbus 1966: 12), saavad järgnevatel kümnenditel kinnituse empiirilistes uurimustes (nt Pajusalu 1987).

Perifeersus ja sisserändajate vähesus on üldiselt aidanud kohamurdeid säilitada. Kolme põlvkonna sünnikohti võrreldes on küsitluste põhjal pakutud, et erinevalt Saare- ja Võrumaast võib sisseränne Mulgimaale olla olnud palju suurem; Saaremaal on põliselanike osakaaluks hinnatud kolm neljandikku ja Võrumaal pool täiskasvanud elanikkonnast (Eichenbaum, Koreinik 2008). Suurest põliselanike ja seega ka potentsiaalsete murdekasutajate osakaalust hoolimata on Võru murde (pro keele) olukorda keeleökoloogilisest vaatenurgast hinnatud ELDIA projektis rakendatud kestlikkuse skaalal „tõ- 
siselt ohustatud” ja „käimasoleva keelevahetuse” vahepealsena (vt Koreinik jt 2013). Toetudes sotsiolingvistikas laialt tuntud Joshua Fishmani (1991) keelte ohustatuse 8-pallilisele skaalale, väidab ka Martin Ehala (2006), et võru keele põlvkondadevaheline edasikandumine on katkenud. Samas näitas juba perifeerse Vastseliina Sute küla keelehoiakute kvalitatiivne analüüs 1990. aastate alguses, et murdeidentiteeti väärtustatakse ja hoitakse, küll aga räägivad pärast 1935. aastat sündinud põlvkonnad kohalikku murret/murrakut eeskätt lähemas perekonna- ja sugulasteringis ning omas maakonnas (Org jt 1994: 207-209). Sute küla vanema põlvkonna keelehoiakutes oli lahkarvamusi rohkem, nii selles, kas kohalikes ametiasutustes murdekeelt kasutada, kui ka selles, kas murret ja kirjakeelt üksteisest lahus hoida (Org jt 1994: 207).

2011. aasta rahvaloendusega avanes unikaalne võimalus täpsemalt uurida, kuivõrd Eesti elanikud arvavad veel olevat Eestis murdeid-murrakuid ja/ või kohalikke keeli. Rahvaloenduse ankeete võisid täita vähemalt 15-aastased Eesti püsielanikud (Kokkuvõte... 2013: 2). Püsielanikeks määratleti inimesed, kes olid Eestis pidevalt elanud vähemalt 12 kuud enne 31. detsembrit 2011 või kes olid Eestisse elama asunud 2011. aastal enne 31. detsembrit ja kavatsesid siia jääda vähemalt üheks aastaks. Püsielanikeks loeti veel ka välismaal töötavad inimesed, kes enamiku vabadest päevadest veedavad Eestis oma leibkonna juures; sõja- ja mereväetöötajad ning diplomaatiline personal ja nende pered, kes loenduse ajal viibivad välismaal, ning vahetus(üli)õpilased (Keda... 2011). Esiteks küsiti inimeselt, kas ta oskab mõnda kohalikku keelekuju, murret või murrakut. Kui inimene vastas sellele jaatavalt, paluti tal nimetada see kohalik keelekuju, murre või murrak, mida ta (kõige paremini) oskab. Ankeedi küsimusel oli seitse valikvastust ja ka vabatekstilise vastuse võimalus. Seitsme valikvastuse hulka kuulusid Kihnu, Mulgi, Saare, Setu, Võru, Kodavere ja Hiiu (Isikuankeet 2011).

Üht-teist viimase loenduse käigus kogutud keele- ja murdeoskuse hinnangute kohta on juba avaldatud (nt Koreinik, Tender 2014; Kommel 2013). Vaagitud on ka loenduseelse poliitika ja aktivistide lobitöö võimalikku mõju tulemuste valiidsusele (Jääts 2013, 2015). Lähtume sellest, et keeleteaduslikust seisukohast võib koos traditsioonilise, paikse eluviisi kadumisega sedastada küll traditsiooniliste kohamurrete hääbumist, ent kui inimesed ise tajuvad kohamurdeid ja hindavad oma keeleoskust piisavaks, siis ei ole veel alust keele- või murdekadu nentida. Seega muutub ebaoluliseks, kuidas teha vahet n-ö tegelikul oskusel ja hinnangutel. Meie artikli üks põhifookusi on uurida murdeoskuse hinnanguid ühiskeelsemas Eestis, eemal kohamurrete kasutuse poolest tuntud perifeeriatest Kagu-Eestist ja saartest. Nende kahe perifeeria murdeoskuse ja -kasutuse kohta on avaldatud mitmeid uurimusi (Pajusalu 1996; Eichenbaum, Pajusalu 2001; Eichenbaum, Koreinik 2008 jt). Peale selle huvitab meid, kas ja kuivõrd on alles teadmine murrakutest, kas on selliseid piirkondi, milles kõneldud murrakuid pole loenduse käigus nimetatud. 


\section{Murre kui sotsiaalne fakt}

Murrete keelelist uurimist on pea alati ühel või teisel moel saatnud ekstralingvistiliste teguritega arvestamine. Juba XX sajandi alguses märkis Antoine Meillet (1904) keelemuutustest rääkides, et keel on silmatorkavalt sotsiaalne fakt või fenomen (pr le langage est donc éminemment un fait social). 1960. aastatel muutus keeleteaduses domineerivale strukturalismile vastukaaluks sündinud sotsiolingvistikas eriti oluliseks arvestamine kõnelejate sotsiaalse tausta ja erinevate keskkondade mõjuga keelele (Hymes 1962; Labov 1966). ${ }^{1}$ Erinevad sotsiolingvistika koolkonnad (nt variatsionism, interaktsionism, võrgustike teooriad, kriitiline sotsiolingvistika, ajalooline sotsiolingvistika, keelesotsioloogia) võtavad suuremal või vähemal määral arvesse poststrukturalismist ja ühiskonnateooriatest tuntud seisukohti keele ja võimu seotusest (Gramsci 1971, 1985; Foucault 1972, 1980; Bourdieu 1991): kuidas võimust lähtuvad sotsiaalne struktuur ja domineerivad diskursused kujundavad inimeste (keelelist) käitumist. Võimu all ei mõisteta siin üksnes riigivõimu, vägivalda või sundust, võim on ,igasugune tõenäosus realiseerida mingi sotsiaalse suhte raames oma tahet vaatamata vastuseisule ning sõltumatult sellest, millel selline tõenäosus rajaneb" (Weber 1968).

Rahvusloomediskursustes on inimeste keelekasutust positsioneeritud hierarhiliselt: ühel keelel või keelevariandil on ühiskonnas suurem kaal ja prestiiž kui teisel. Keelehierarhiaid mõjutavad (keele)poliitikad - nii tahtlikud kui ka tahtmatud -, aga ka ühiskonnagruppide ettekujutused keeltest, st keeleideoloogiad, mis (taas)loovad sotsiaalseid erinevusi (Blackledge 2005). Konstruktsionistlikust vaatepunktist on sotsiaalne reaalsus (see, mida arvatakse olevat või eksisteerivat) ainuke reaalsus (vrd Berger, Luckmann 1966). Näiteks on sellised sotsiaalsed konstruktsioonid nagu etniline identiteet ja muu grupikuuluvus või -lojaalsus ning nende vahele inimeste poolt tõmmatud piirid oma tagajärgedes ülimalt reaalsed: imaginaarsetest piiridest võivad alguse saada keelemuutused, neist võib lähtuda keelekasutus. Ometi pole sotsiolingvistika sugugi ühtne ja ollakse eri meelt selles, kas sotsiolingvistikal on või peab olema „oma” teooria (vt nt Coupland 2001). Ka ei ole „keelelise” ja „sotsiaalse” seos sotsiolingvistikas üksühene, nende vahekorra puhul võib olla tegemist: 1) nii sotsiaalse kui ka keelelise rõhutamisega ehk sotsiolingvistika tegeleb sotsiaalsete küsimustega, millel on keeleline komponent; 2) sotsiaalselt realistliku keeleteadusega, mis uurib reaalse ühiskonna keelekasutust, mitte keelt kui abstraktset süsteemi; 3) sotsiaalselt konstitueeritud keeleteadusega, mille järgi keeleteadus on seesmiselt sotsiaalne ja ühiskond on seesmiselt keeleline (Hymes 1974: 95).

Sotsiolingvistikale lähedane on ka etnodialektoloogia, mis keskendub tavakõnelejate hinnangute, taju, arvamuste ja suhtumiste analüüsimisele (Preston 1999: xxv). Etnodialektoloogia paigutub makrolingvistika alla, uurides keelt koos kultuuriliste, käitumuslike ja ühiskondlike teguritega, st kõige laiemas tähenduses. Etnodialektoloogia kõige nimekamaid uurijaid Dennis R. Preston on lähtunud nii traditsioonilisest dialektoloogiast kui ka sotsiolingvistikast ning liitnud oma meetodisse kultuurigeograafide kujutluskaartide (ingl

\footnotetext{
${ }^{1}$ Loomulikult ei tekkinud sotsiolingvistika tühjale kohale. Nii näiteks on keele varieerumise tänapäevasele sotsiolingvistilisele uurimisele aluse pannud William Labov tunnistanud, et ei oska enam öelda, kui palju ideid on ta saanud oma mentorilt Uriel Weinreichilt ja kui palju on neid ise keeleteadusesse toonud (vt nt Kim 2011: 101).
} 
mental maps) kontseptsiooni (Preston 1989: 14-21). Prestoni meetodis on oluline osa ülesannetel, kus lastakse inimestel märkida kaardile kõik neile tuntud murdealad (Preston 1999: xxxiv). See, mida tavakõneleja peab murdeks ja mida mitte, näitab eristust normikeele ning normist kõrvalekaldumise vahel: mõlemaga on seotud omad hinnangud, väärtused ja stereotüübid. Normikeelt (näiteks riigi- või ühiskeelt) peavad selle kõnelejad korrektseks ning nad ei tunne üldjuhul keelelist ebakindlust; normist erineva keelekuju rääkijad rõhutavad aga pigem kohaliku keele meeldivust (sõbralikkus, viisakus) ning peavad standardkeelt kõrgiks, külmaks ja kunstlikuks (Niedzielski, Preston 2000: 44; Preston 1999: xxxiv).

Sarnaselt sotsiolingvistikaga on ka etnodialektoloogias keele prestiiži uurimisel oluline koht. Etnodialektoloogilistes uurimustes on leitud sedagi, et suure prestiižiga keelekuju levikut iseloomustab n-ö kiirgusefekt (ingl radiation effect): tavakõnelejad peavad prominentseid murdealasid suuremateks, kui need isoglosside poolest tegelikult on (Fought 2002: 115). Sel moel võib prominentse murdeala nimi levida kaugemale ja katta ka teisi murdeid, iseäranis kui need on sellega keeleliselt sarnased. Ülimitmekesisuse (ingl superdiversity) ajastul muutub tähtsaks ühe või teise kõnepruugi või keelemarkeri autentsus, mille konstrueerib ja seob oma identiteediga keelekasutaja ise (vrd Blommaert, Varis 2013). Küsitluse käigus ei ole võimalik kindlaks teha, mil määral võrdlevad keelekasutajad keeleoskust minevikupraktikatega, mil määral kaaluvad seda abstraktse normikeele või keskmise ühiskeele suhtes. Murded teisenevad ja keeleteadlaste võimuses on vaid nentida traditsiooniliste (kuni XX sajandini kõneldud) murrete hääbumist, ent milliseid tähenduslikke piire oma ja võõra, meie ja nende, autentsuse ja mitteautentsuse vahel tõmmatakse, otsustavad murdekasutajad ise. Seega on murded ja murdejooned kui osa keelelisest variatiivsusest just niivõrd reaalsed, kuivõrd inimesed arvavad neid reaalsed olevat. Kui keelekasutajad arvavad, et nad oskavad mõnda kohalikku keelekuju, siis on sellel reaalsed tagajärjed: neid võidakse elavdada või taastada, aga ka nende kasutamist kritiseerida või koguni taunida, neid ühiskeelsema kõnepruugi vastu vahetada.

\section{Murrete märkimine rahvaloenduses}

2011. aasta rahvaloenduses märkis umbes $15 \%$ eesti emakeelega püsielanikest murdeoskust. Kõige rohkem märgiti Võru (74 512), saarte (24 520, sellest Kihnu 1319), Setu (12 532) ja Mulgi (9682) murret. Esimene kaart näitab murdeoskajate osakaalu kõigist püsielanikest valdade kaupa, arvestades kõiki murdeid, mida mingi piirkonna inimene märkis. Seega näitab kaart 1, kus kõige rohkem murdeoskajaid elab. Oli vaid kaks valda, kus murdeoskust üldse ei märgitud: Piirissaare ja Alajõe. Piirissaare puhul on põhjuseks see, et väikese saare püsielanikkonna moodustavad vene vanausulised, kes on teadlikult püüdnud hoida oma eripärast kultuuri ja kombestikku (Piirissaare... 2014). Teisalt võib olla põhjuseks lihtsalt rahvaloenduse küsitleja mõju. Ka Alajõe vallas moodustavad enamuse ( $86 \%$ ) vene emakeelega inimesed (Alajõe... 2011). Nähtavasti pole ka sealsetel eesti emakeelega inimestel murretega eriti kokkupuuteid. 


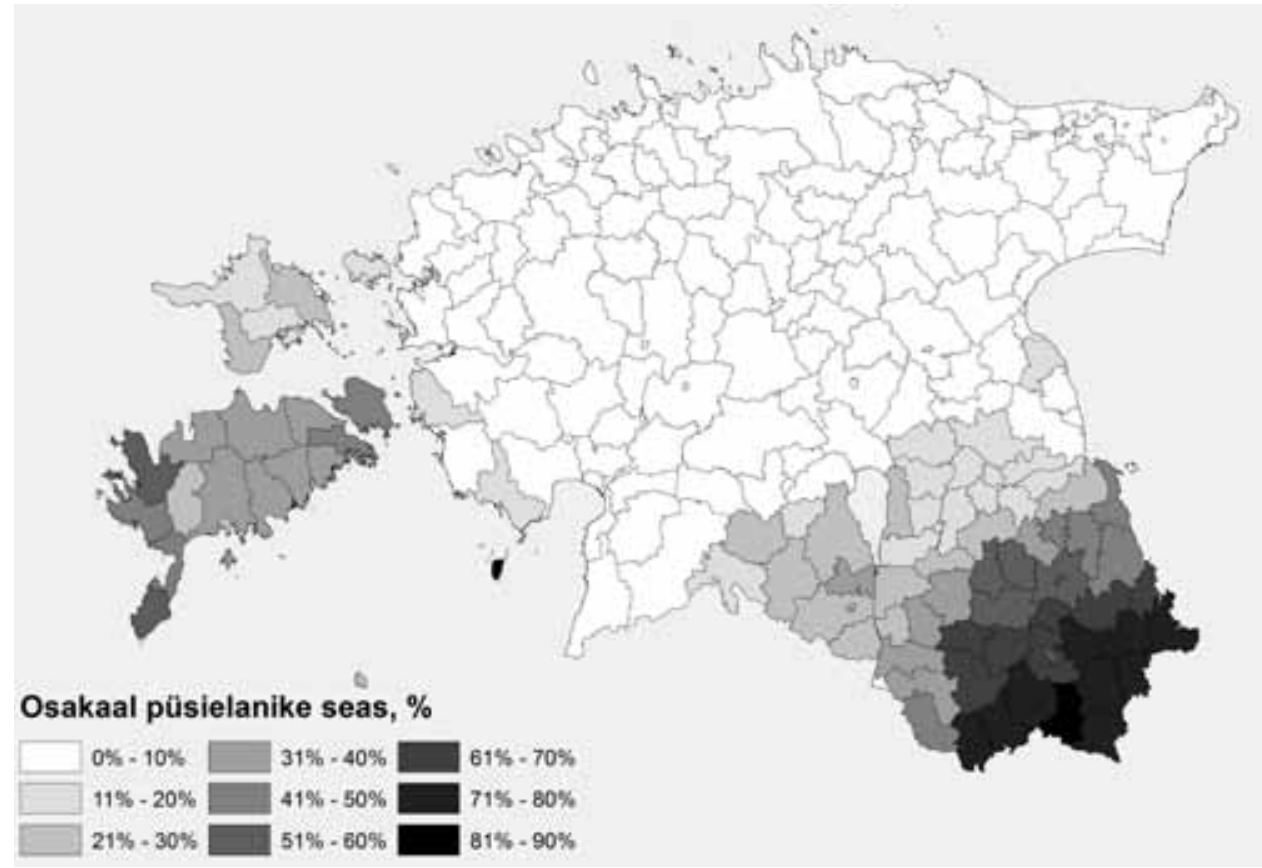

Ka art 1. Murdeoskuse märkinute osakaal kõigist püsielanikest.

Kaardilt 1 on näha, et Põhja- ja Kesk-Eestis on murdeoskust märkinute osakaal valdavalt väiksem kui $11 \%$. See suureneb aga kahes piirkonnas: Lõuna-Eestis (traditsioonilisel lõunaeesti peamurdealal) ning Lääne- ja EdelaEesti saartel. Ajaloolisel Mulgi murde alal märkis murdeoskust umbes kümnendik kuni kolmandik vastanutest ja Tartu murde alal 11-22 \%. Mida kaugemale keskustest, seda suuremaks murdeoskusega inimeste osakaal muutub. Kõige rohkem (kuni 86 \% püsielanikest) on neid piiriäärsetes valdades: Varstus, Haanjas ja Missos. Veidi erandlik on Võru vald ja linn, kus murdekõnelejate osakaal on umbes kümnendiku võrra väiksem.

Saartest kõige suurema murdeoskuse osakaaluga on Kihnu (85 \% püsielanikest). Saaremaal on murdeoskajate osakaal veidi suurem kui Hiiumaal, iseäranis tõusevad esile Muhu saar ning Kihelkonna ja Torgu vald. Viimastel on eeldatavasti tugevam kohaidentiteet, mida üldisest saarlusest püütakse eristada (nt näitlikustab seda n-ö Torgu kuningriik). Kaardilt 1 on näha sedagi, et nendes Lääne-Eesti mandrivaldades, mis asuvad saartele kõige lähemal teispool merd, on ka rohkem murdeoskust märkinud inimesi. Nii on näiteks Tõstamaa ja Hanila vallas murdeoskajate osakaal 11-22 \%.

Rahvaloenduse andmete põhjal on Eestis kolm piirkonda, kus murdeoskajad moodustavad vähemalt poole püsielanikest: Kihnu saar, Kihelkonna ja Torgu vald ning Kagu-Eesti. Kuna traditsioonilisi kohamurdeid ja teiste piirkondade murdeid 1. kaardil pole eristatud, siis ei saa öelda, kas ja kuidas on inimeste ja/või koos nendega ka murdenimetuse ränne murdeoskust märkinute osakaalu mõjutanud. Nendele küsimustele võib aga tuua selgust 2. kaart. 


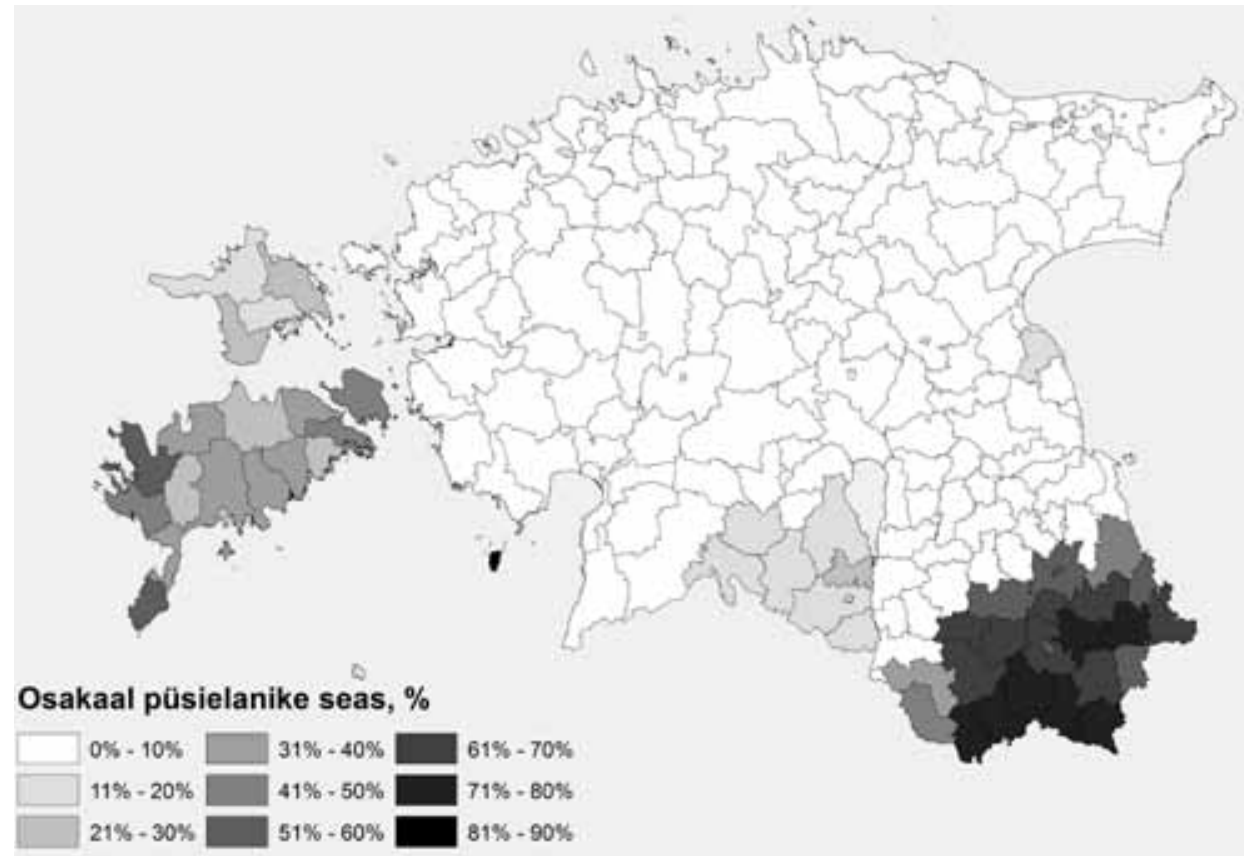

Kaart 2. Piirkonna traditsioonilist kohamurret märkinute osakaal kõigist püsielanikest.

Kaart 2 näitab, kui suur osakaal püsielanikest märkis piirkonna traditsioonilist kohamurret ning peaks seega andma mingi ülevaate kohaliku murde teadlikustamisest ja eristamisest tänapäeval. Kaardil on osakaalud esitatud taas valdade kaupa, kuna rahvaloenduse andmed on kogutud ja jagatud valdade kaupa, ent analüüsimisel püüdsime viia vallad ja kihelkonnad vastavusse.

Kui võrrelda 1. ja 2. kaarti, siis on need suuresti sarnased. Siiski on mitmeid olulisi ja kõnekaid erinevusi. Mandri-Eestis on vahest silmapaistvaim erinevus traditsioonilisel Tartu murde alal. Kaardilt 2 on näha, et Tartu murde märkimise osakaal selle traditsioonilisel alal on niisama väike kui Kesk-, Kirde-, Põhja- ja Lääne-Eestis. Andmestikku lähemalt analüüsides selgub, et märgatavalt rohkem on sealsed elanikud märkinud Võru murde oskust. Niisiis võib oletada kas elanike väljarännet Võrumaalt või lihtsalt Võru murde dominantsemat positsiooni Lõuna-Eestis ning selle nimetuse kiirgusefekti lähivaldadesse olukorras, kus teisi traditsioonilisi murdeid enam nii väga ei teata. Suurema osakaaluga tõuseb esile ka traditsioonilise Kodavere murraku alale jääv Alatskivi vald. See on ainus idamurde ala, kus murdeoskust märkis enam kui kümnendik püsielanikkonnast. Võru murde oskajate kõige suurem osakaal on koondunud suuresti Eesti kagupiiri äärde ja märkimisväärseid erinevusi kaartide vahel pole.

Saarte murret on rohkem märgitud ka meretagustes naabervaldades, nt Hanilas, ja Kihnu murrakut Tõstamaal. Samas on mõnel Lääne-Eesti saarel Võru murret märkinud inimesi rohkemgi kui saarte murret märkinuid, nt 
Vormsil. Üldiselt pole aga 1. ja 2. kaardi kõrvutamisel suuri erinevusi saartel näha: sarnane on seegi, et Hiiumaal on murdeoskust märkinute osakaal väiksem kui Saaremaal. Suurema kohaliku murde oskusega eristuvad Kihnu, Muhu, Kihelkonna ja Torgu.

Eespool mainisime, et oli vaid kaks valda, kus üldse murdeoskust ei märgitud. Neid valdu, kus ei märgitud kordagi traditsioonilist kohamurret, oli aga koguni 46, vt kaarti 3.

Ootuspärane on see, et need vallad paiknevad traditsioonilisel Kesk-Eesti murdealal, kus erinevused murrete ja normikeele vahel pole väga suured. Kuid ka üksikutes läänemurde alale jäävates valdades pole kordagi märgitud traditsioonilist kohamurret. Samuti pole märgitud idamurret Peipsiääre vallas, mis sarnaselt Piirissaarega on peamiselt venekeelsete vanausuliste elupaik (Peipsiääre... 2012). Samuti mitmes lõunaeesti peamurde piiriga külgnevas vallas pole kordagi märgitud kohalikku murret või murrakut. Kolmandat kaarti esimesega võrreldes tekib paratamatult küsimus, mis murret siis nendes valdades märgiti. Järjekordselt selgub andmetest, et kõige rohkem on märgitud Võru murret, selle kõrval on aga ka palju saarte ja Mulgi murde oskust esitanuid. Traditsiooniliste kohamurrete säilimise osas on selge, et kohalik murdeidentiteet ja -keel on paremini püsinud Eesti äärealadel.

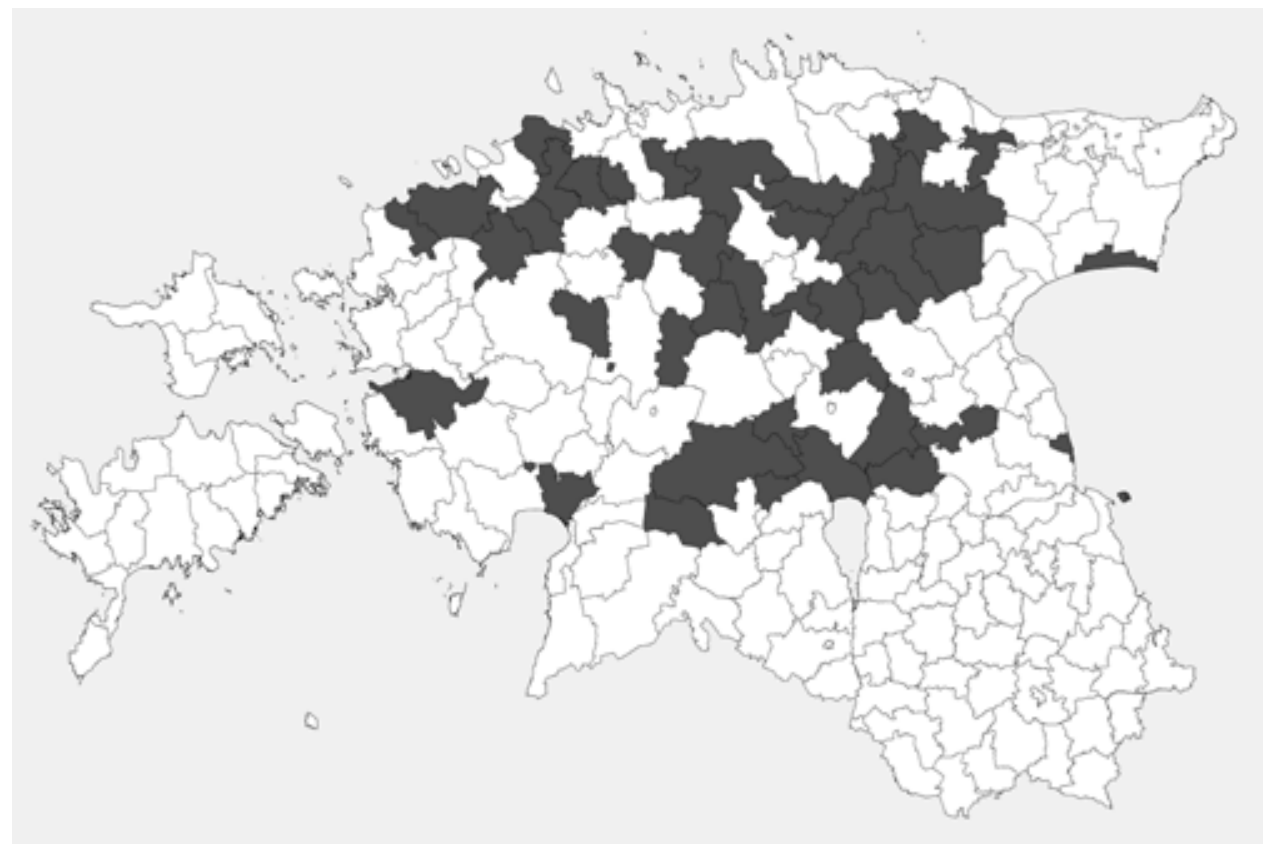

Ka art 3. Vallad, kus ei märgitud traditsioonilist kohamurret. 


\section{Murrakute ja muude kohalike keelekujude märkimine rahvaloenduses}

Rahvaloenduse ankeedis oli kohaliku keelekuju oskuse küsimuse juures võimalik anda ka vabatekstiline vastus (Muu). Nii sai inimene märkida muid või väikseimaid kohalikke keelekujusid. Kokku esitati umbes 9800 vabavastust. Nende põhjal uurisime kõigepealt, kas kõiki traditsioonilisi (kihelkondadel põhinevaid) murrakuid on nimetatud. Murrakute puhul uurisime esmalt nende oskuse märkimist kvalitatiivselt: kui murrakut on vähemalt korra nimetatud kihelkonna nimega, siis seda veel tajutakse eristuvana ja autentsena. Kaardil 4 on märgitud need kihelkonnad, mida ei nimetatud. Teiseks vaatasime, milliseid nimesid on kasutatud kohalike keelekujude märkimisel. Kuna ankeedis küsiti kohaliku keelekuju, mitte konkreetselt murde/murraku kohta, siis leidus ka vastuseid, mida traditsiooniliselt murreteks või murrakuteks lugeda ei saa (nt pilavastused, nagu Varese kraaksumise murrak, ja allkeeled släng, pi-keel, pudikeel, Tallinna tööliskeel, Tallinna newspeak, Getto, 1337).

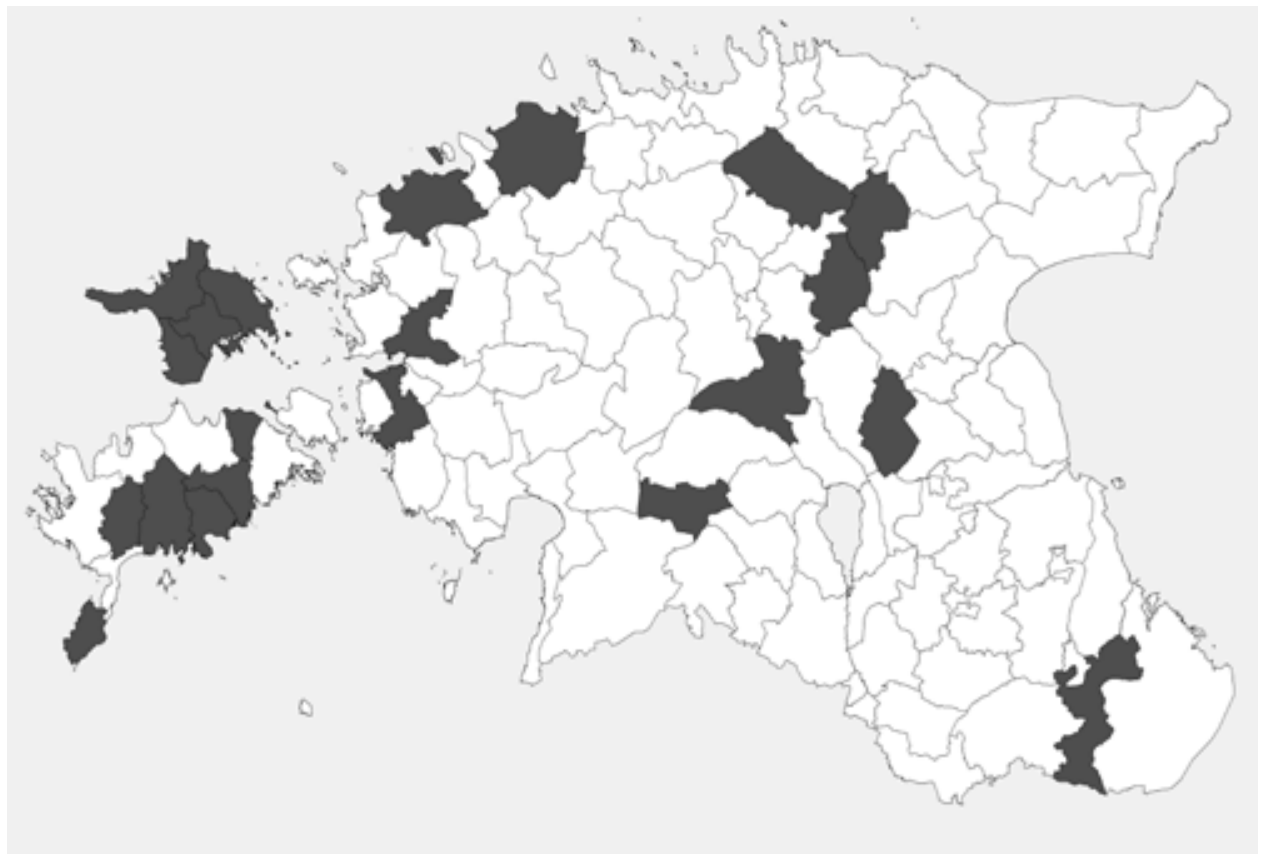

Ka a rt 4. Murrakud, mida ei nimetatud (tähistatud halliga).

Valdavalt märgiti vabavastustes murrakuid või kohalikke keelekujusid mingi haldus- või asustusüksuse järgi. Sagedasti kasutati muidki täpsustavaid nimetusi, nagu ranna, rannarahva, randlase murre, Ranna-Eesti; Tõstamaa, rannaala; Pärnu rannarahvas. Nende seas oli ka mitmest osast koosnevaid kohaliku keelekuju nimesid (nt lääne-saare). Osa neist võivad märkida mitmikidentiteeti, teised aga kohaliku murde/murraku täpsemat piiritlemist. Vabavastuste seas oli neidki piirkondlikke nimetusi, mida võidi varem pidada 
halvustavaks (nt junlased ja ubamulgi). Samas tuleb tähele panna, et neid kasutasid vastajad enda kohta. Ei saa päriselt öelda, et need oleks pejoratiivse tähenduse kaotanud, ent sellele vaatamata kasutasid inimesed neid oma päritolu ja identiteedi määramisel.

Kaardi 4 põhjal saab analüüsida, mis murrakualasid on tajutud ühtse tervikuna. On näha, et enamikku murrakuid on vähemalt korra nimetatud. Kui võrrelda 3. kaardiga, siis on märgata, et ka Kesk-Eestis on vähem puuduvaid keelekujusid. Seega isegi väikese murdekõnelejate osakaalu puhul teadsid või tajusid mõned inimesed kohalikke traditsioonilisi (kihelkonna)murrakuid. Ootuspärane oleks olnud, et 3. ja 4. kaart on suuremas vastavuses, st valdades, kus murdeoskust märkis vähem inimesi, ei tunta ka kohalikke murrakuid, kuid see ei olnud nii.

Kagu-Eesti murrakutest pole ainsana nimetatud Vastseliinat. Kindlaid põhjuseid siin tuua on keeruline. Seletuseks võib olla see, et kuna Vastseliina on Võru murde tähtsamaid keskusi ja tuumalasid, siis pole inimesed tundnud vajadust seda eraldi murrakuks eristada. Lääne-Eesti saartel on märgata, et mitut murrakut pole nimetatud kordagi, iseäranis just Hiiumaal, kus pole nimetatud ühtegi murrakut saare nelja ajaloolise kihelkonna järgi. Eelmistel kaartidel esitatud andmed aga osutavad, et murdeoskust märkinute osakaal oli seal küllaltki suur. Seega tuleb arvata, et Hiiumaa murrakurühma tajutakse ühtsena. Sarnasele järeldusele on jõudnud ka Kutt Kommel (2013). Saaremaal on nimetatud pooled murrakutest, sh Kihelkonna ja Muhu, kus murdeoskajate osakaal oli vähemalt $50 \%$ püsielanikest. Küll aga pole nimetatud Jämajat, kuigi Torgu vallas märkis samuti vähemalt pool püsielanikest murdeoskust. 5. kaardilt, mis esitab teisi kohalike keelekujude nimetusi, on näha, et Jämaja murraku asemel on sealsed elanikud kasutanud hoopis Sõrve nime. Järelikult on sealne tugev murdeidentiteet seostatud kogu Sõrve poolsaarega.

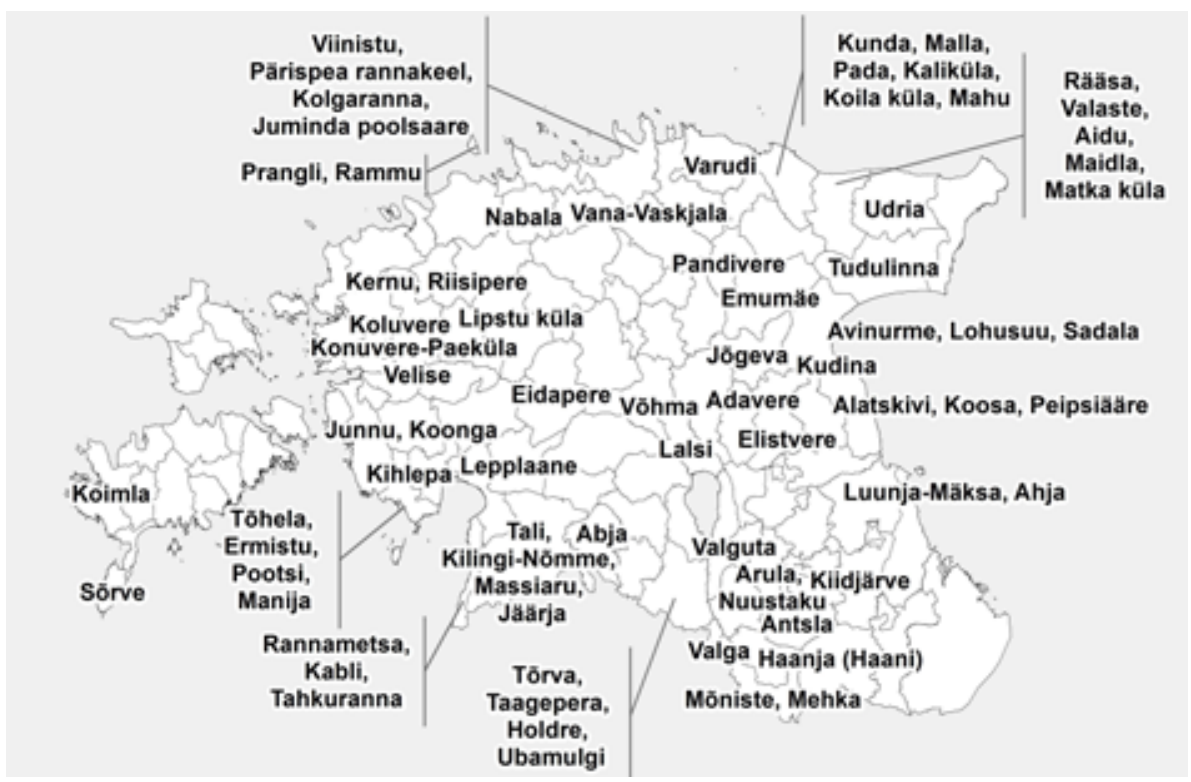

Ka a rt 5. Teised nimetatud kohalikud keelekujud Eesti valdade kaardil. 
Veel näitavad kaardi 5 andmed, et mandri äärealadel on tunduvalt rohkem märgitud murrakust väiksemaid kohamurdeid, Kesk- ja Kagu-Eestis ning Lääne-Eesti saartel on neid nimesid märgatavalt hõredamalt. Tähelepanuväärne on, et kuigi näiteks kirderannikumurret märgiti $11 \%$ või vähem, eristavad sealsed väikesed kogukonnad end väga selgelt üksteisest.

\section{Jõhvi ja Lüganuse valla lähianalüüs}

Saamaks täpsemat ülevaadet, kuidas ühe piirkonna perifeersete lähivaldade sees kohalikke murdeid ja murrakuid nimetati, kandsime kaartidele Jõhvi ja Lüganuse valla vabavastused, vt 6 . ja 7 . kaart.

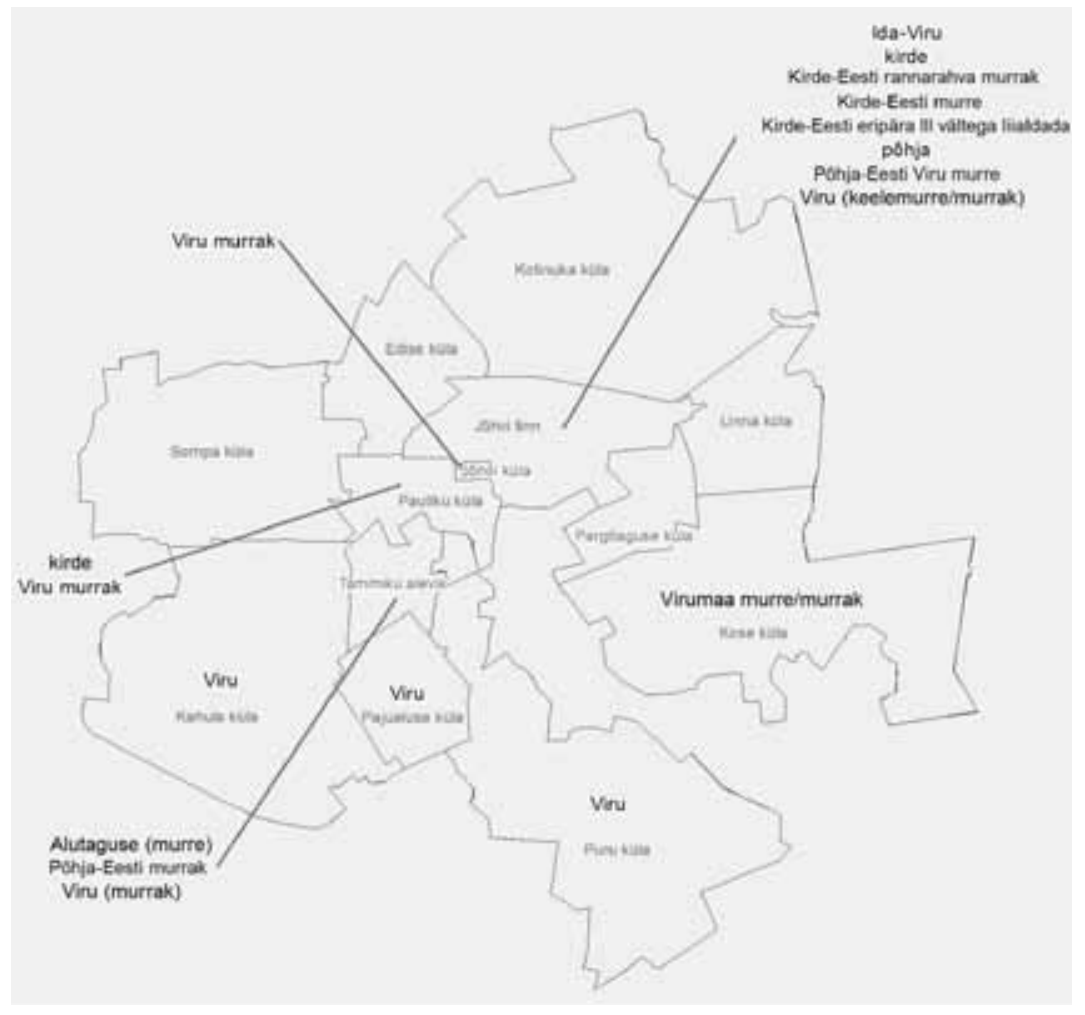

Ka art 6. Jõhvi valla vabavastused.

Jõhvi valla vabavastused saab jagada nelja suuremasse rühma nimetamise viisi järgi: 1) Viru või Virumaa (28 korda); 2) kirde või kirde-eesti (5); 3) põhja või põhjaeesti (3); 4) Alutaguse (2). Teist ja kolmandat rühma iseloomustab kohalikule keelekujule nimetuse andmine ilmakaarte järgi. Kuigi täpset (ega ka umbmäärast) murdeulatust ei saa rahvaloenduse andmete põhjal määrata, võib siiski oletada, et siin põhjaeesti määratlus erineb dialektoloogiast tuntud põhjaeesti peamurdest. Ilmselt on sealsete püsielanike jaoks põhjaeesti kitsama ala murde nimetus, mis võib seostuda põhjarannikuga. Kirde-Eesti võib olla põhjaeestist nii lokaalsem kui ka laiem määratlus, kuid see on siiski selgema kohaliku taustaga. Ainult üks vastanu määratles kohalikku murret/ 
murrakut kui Kirde-Eesti rannarahva murret/murrakut. Nende andmete põhjal ei ole enda rannarahvaks nimetamine üldisemalt Jõhvi vallale tüüpiline.

Esimene ja neljas rühm vastuseid seostuvad aga üsna kindlalt suurema piirkonnaga ning neid on võimalik tinglikult ka piiritleda nimetuste põhjal. Nii Viru(maa) kui ka Alutaguse nimetus lähtub kas praegusest või ajaloolisest haldusjaotusest. Need kaks nimetuste rühma põhinevad selgelt ajaloolisel halduslikul ja miks mitte ka kultuurilisel määratlusel. Ülekaalukalt kõige rohkem ongi kohalikku murdekeelt Jõhvi valla erinevates külades nimetatud Viru või Virumaa keeleks, murdeks või murrakuks. Kahel korral on kohalikku keelt nimetatud kitsamalt idaviru keelekujuks. Seega suurem osa vastanutest nimetab kohalikku keelt ajaloolise maakonna nime järgi, tunduvalt vähem on kasutatud ka praegust maakonna nimetust.

6. kaart näitab ka, et märksa rohkem erinevaid vastuseid on inimesed märkinud valla suuremates keskustes: Jõhvi linnas ja Tammiku alevikus. Põhjus võib olla elanike arvus: mida suurem küsitletute arv, seda rohkem ja erinevaid vastuseid. Kõige rohkem vastatigi vabavastusega Jõhvi linnas (14) ja Tammiku alevikus (8), kuid ka Kahula külas (8). Teised vastused jagunesid lähikülade vahel ilma selge paiknemismustrita. Kahula küla on 2011. aasta statistika järgi rahvaarvult 133 elanikuga neljas küla Jõhvi vallas (Jõhvi... 2011). Kahula küla on märkimisväärne seetõttugi, et sealsed vabavastused olid kõik ühel ja samal kujul: Viru. Rahvaloenduse puhul ei saa välistada grupiviisilist ankeetide täitmist, eeskätt ühe perekonna sees, ning ka küsitleja mõju. Seda võib oletada ka teiste Jõhvi valla külade puhul, kus korduvad kaks kuni kolm korda samakujulised vabavastused. Kahula küla kaheksa samakujulist vastust justkui viitaks eeldatavasti mitte ühele perekonnale, vaid veidi suuremale rühmale, kes omavahel suhtlevad. Kuigi külaelanikest moodustab kaheksa vastust marginaalse osa, võib see siiski märku anda Kahula küla elanike huvist oma kohaliku keele vastu. Seda arvamust tugevdab mõneti seegi, et Kahulas tegutseb külaselts (Kahula... 2014).

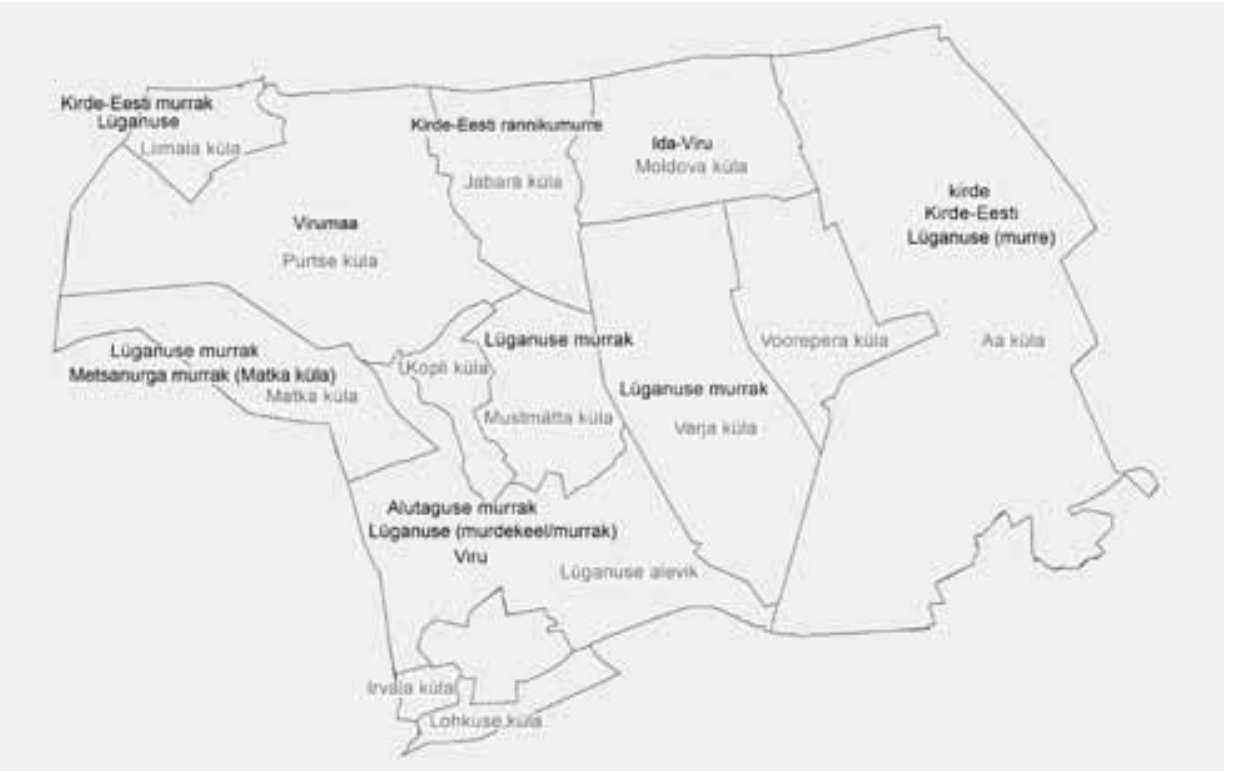

Ka a r t 7. Lüganuse valla vabavastused. 
Lüganuse valla vabavastused saab jagada kolme suuremasse rühma: 1) Lüganuse (18 korda); 2) (Ida-)Viru või Virumaa (11); 3) kirde või kirde-eesti (4). Kaardilt 7 on näha ka Alutaguse, ida ja metsanurga (Matka küla) murrakut, ent kõiki neid esines vaid üks kord. Kuigi tavapärase eesti murdejaotuse järgi ei jää Lüganuse vald idamurde alale, mistõttu võiks seda määratlust pidada sama võõraks kui Võru murret, on tõenäone, et vastanu võis märkida lihtsalt laiemat piirkonda ilmakaare järgi, teadmata midagi eesti dialektoloogiast.

Kui võrrelda nende kahe valla vabavastuste rühmi, siis kaks Lüganuse rühma kattuvad Jõhvi omadega. Seda sarnasust võis ka eeldada kahe lähivalla puhul, mis kuuluvad ajalooliselt samasse murderühma. Siiski on kummaski vallas antud vastuseid, mida teises pole (nt Lüganuse, ida, põhja). See, et Lüganuse murret/murrakut vaid samanimelises vallas märgiti, on arusaadav. Samas on tähelepanuväärne, et Jõhvis ei märgitud kordagi kohalikku keelekuju valla/kihelkonna järgi, ehkki Lüganuses nimetati valla/kihelkonna järgi antud vabavastuseid ülekaalukalt kõige rohkem. Võib-olla on siin põhjuseks asjaolu, et Jõhvi seostub tänapäeval ennekõike piirkonna suurima keskusega, st Jõhvi linnaga, Lüganuse aga ajaloolise piirkonnaga. Arvukuselt teisena oli Lüganuse vallas kohalikku keelekuju nimetatud ka (muinas)maakonna Virumaa järgi, kuid see nimetus ei olnud nii valdav kui Jõhvi vallas. Kuigi märkimisväärne osa Lüganuse elanikest samastab oma kohalikku murdekeelt laiemalt Viru(maa) murde/murrakuga, on seal veel rohkem inimesi, kes määratlevad oma murdeoskust kitsamalt. Huvitav on seejuures, et üle poole Lüganuse murret/murrakut märkinud inimestest ning üle $80 \%$ Viru(maa) murret/murrakut märkinud inimestest elavad valla keskuses Lüganuse alevikus. Teised vabavastustes märgitud murded/murrakud on jaotunud valla külade vahel ning selget geograafilist mustrit nende murrete/murrakute paigutuses ei ilmne.

Hiljutise kooliõpilaste murdetundmise etnodialektoloogilise uurimuse (Antso 2015) tulemused näitavad, et noorte (10. ja 11. klassi õpilaste) murdetaju Eesti erinevates piirkondades ühtib suuresti selle pildiga, mida annab meile rahvaloendus. Nii Lõuna-, Lääne- ja Kirde-Eesti kui ka Saaremaa noorte vastustes oli kõige enam märgitud Võru ja saarte murret. Üldiselt tundsid noored lähiümbruse murdeid paremini kui kaugemaid (näiteks Lääne-Eesti ja Saaremaa õpilased märkisid märksa enam erinevaid saarte murrakurühmi kui Kirde- ja Lõuna-Eesti noored). Erandlikud olid juba mainitud Võru ja saarte murre, millel, nagu näha, on tugev ja kinnistunud positsioon mitme erineva murdeküsitluse põhjal.

Ennast ise traditsioonilise kohamurde kõnelejaks märkisid Kirde-Eesti, Võru ja Saaremaa noored. Seejuures nimetasid Kirde-Eesti noored oma kohamurret idamurdeks ning piiritlesid selle suuresti Ida-Virumaaga (vrd Hiiumaa muutunud murdeidentiteediga). Tartus ja lääne-eestilises Pärnu-Jaagupis märkis kodukoha murret alla $15 \%$ noortest. Need tulemused noorte murdetaju kohta väljendavad vast vahetumalt võimalikke perspektiive murrete positsiooni edasisest muutumisest Eesti eri piirkondades. 


\section{Kokkuvõte}

Kuigi rahvaloenduse kohaliku murde/keele oskuse küsimise viisi ja saadud andmetesse saab suhtuda ka kriitiliselt (Jääts 2013), annavad tulemused mingigi üldistava pildi Eesti elanike praegusest murdeoskusest ja eesti ühiskeelest erinevate keelekujude tajumisest. Traditsiooniliste murrete tegeliku oskusega ei tasu loenduse tulemusi siiski siduda. Kõige olulisem järeldus on vast tugeva murdeoskuse ja -kasutusega seotud identiteedi ja identiteediloome (identiteedipoliitika) ning Eesti-sisese rände võimalik mõju mingi piirkonna murdekõnelejate suhtelisele arvule. Kolme enim nimetatud murret võib leida pea igas vallas ning mõnelgi pool on nende tugeva ja selgepiirilise kuvandiga murrete osakaal veidi suuremgi kui traditsioonilise kohamurde oma. Traditsioonilised kohamurded on elujõulisemalt säilinud Eesti perifeeriates: Lääne-Eesti saartel ja Kagu-Eestis. Kesk-Eestis oli kõige rohkem valdu, kus piirkondlikku kohamurret üldse ei märgitud. Kui aga vaadata murrakuid, siis on näha, et enamikku neist on vähemalt korra nimetatud. Seega ei saa veel päriselt rääkida ka murrakute kadumisest, kuigi ilmneb olulisi keele- ja identiteedimuutusi (nt Hiiumaa murrakute tajumine ühe hiiu murdena).

Vabavastuste analüüsist selgus seegi, et hoolimata murdeoskuse märkinute väiksest osakaalust mingil alal võib kohaliku keelekuju määratluste hulk olla siiski suur ja tähenduslikult varieeruv. Vabavastuste seas olidki kõige levinumad piirkonnast lähtuvad vastused. Seejuures võidi märkida nii eri suurusega ajaloolisi haldusüksusi kui ka kultuuripiirkondi. Kohaliku murdekeele sidumine erinevate lokaalsete identiteetidega sõltub tõenäoliselt nii inimese isiklikust taustast, sh paiksusest, kui ka konkreetse piirkonna eripärast ning sellega seotud nimetuste (mitme)tähenduslikkusestki.

Kohaliku keele- või murdeoskuse püsimist võib pidada konservatiivseks, traditsioonilisi väärtusi ja lokaalset identiteeti hoidvaks nähtuseks. Lisaks põlvkondlikule keeleülekandele ja kooliharidusele aitavad sellele omal kombel kaasa ka näiteks pruunid kihelkonnasildid üle Eesti, kihelkonnapäevad, surnuaiapühad, populaarsust koguv suguvõsauurimine ja seda hõlbustavate säilikute kättesaadavaks tegemine veebis ning muud kohaidentiteediga seotud praktikad ja kohaidentiteeti tahtlikult või tahtmatult kujundavad poliitikad. Teiselt poolt võib kohalike keelekujude oskuse teadvustamist ja väärtustamist seostada hoopis uute ühiskondlike arengutega, seda nii Kirde-Eestis kui ka mujal. Murdeoskuse püsimisele ja elavdamisele aitavad kindlasti kaasa ka keelepoliitilised ettevõtmised, nagu raadio- ja telesaated, õppe- ja ilukirjanduse avaldamine ja levitamine, laste ja täiskasvanute õpetamine, ning alahinnata ei saa ka kodanikualgatusi sotsiaalmeedias jm. Ehkki rahvaloenduse tulemuste põhjal võib öelda, et päriselt on murdekeele oskus alles ainult Kagu-Eestis ja Lääne-Eesti saartel, on neid, kellele kohalik murre on tähtis kas või identiteedi väljendusena, mitmel pool Eestis. See annab ka kohalikele keelekujudele uue eluvõimaluse.

Uurimus on valminud Eesti Teadusagentuuri projektide IUT2-37 „Soome-ugri keelte prosoodiline struktuur ja keelekontaktid” ja IUT20-3 „Eesti keele kestlikkus avatud maailmas (EKKM)" raames. 


\section{Kirjandus}

Alajõe... = Alajõe vald 2011. http://entsyklopeedia.ee/artikkel/alajõe_vald (17. X 2015).

Ants o, Siim 2015. Etnodialektoloogiline uurimus Eesti murdealadest. Magistritöö. Käsikiri Tartu Ülikooli eesti keele osakonnas.

B e r g e r, Peter L., L u ck m a n n, Thomas 1966. The Social Construction of Reality: A Treatise in the Sociology of Knowledge. Garden City, NY: Anchor Books.

Blackledge, Adrian 2005. Discourse and Power in a Multilingual World. Philadelphia, PA: John Benjamins Publishing Company.

B lo m m a ert, Jan, V a r is, Piia 2013. Enough is enough. The heuristics of authenticity in superdiversity. - Linguistic Superdiversity in Urban Areas. Toim Joana Duarte, Ingrid Gogolin. Amsterdam-Philadelphia: John Benjamins Publishing Company, lk 143-160.

B o u r d i e u, Pierre 1991. Language and Symbolic Power. Cambridge: Polity Press.

Coupland, Nikolas 2001. Introduction: Sociolinguistics and Social Theory. Sociolinguistics and Social Theory. Toim Nikolas Coupland, Srikant Sarangi, Christopher N. Candli. London: Routledge, lk 1-28.

Eh ala, Martin 2006. Keelevahetuse pööramisvõimalusi võru keelealal. - Mitmekeelsus ja keelevahetus läänemeresoome piirkonnas. (Võro Instituudi toimõndusõq 18.) Toim Helen Koks, Jan Rahman. Võro: Võro Instituut, lk 11-26.

E i c h e n b a u m, Külli, Ko r e in i k, Kadri 2008. Kuis eläs mulgi, saarõ ja võro kiil? Kohakeelte seisundiuuring Mulgimaal, Saaremaal ja Võrumaal. Võru: Võro Instituut.

E i c h e n b a u m, Külli, P aj u s a l u, Karl 2001. Setode ja võrokeste keelehoiakutest ja identiteedist. - Keel ja Kirjandus, nr 7, lk 483-489.

Fis h m a n, Joshua A. 1991. Reversing Language Shift: Theoretical and Empirical Foundations of Assistance to Threatened Languages. Clevedon: Multilingual Matters.

Foucault, Michel 1972. The Archaeology of Knowledge. New York: Pantheon.

Foucault, Michel 1980. Power/Knowledge: Selected interviews and other writings, 1972-1977. Toim Colin Gordon. New York: Pantheon.

Fought, Carmen 2002. California Students' Perceptions of, You Know, Regions and Dialects? - Handbook of Perceptual Dialectology, Vol. 2. Toim Daniel Long, Dennis R. Preston. Philadelphia, PA: John Benjamins Publishing Company, lk 113-134.

Gramsci, Antonio 1971. Selections from the Prison Notebooks. Toim Quintin Hoare, Geoffrey Nowell Smith. New York: International Publishers.

Gramsci, Antonio 1985. Selections from Cultural Writings. Tlk William Boelhower. Toim David Forgacs, Geoffrey Nowell Smith. London: Lawrence and Wishart.

Hymes, Dell 1962. The ethnography of speaking. - Anthropology and Human Behavior. Toim Thomas Gladwin, William C. Sturtevant. Washington, DC: Anthropology Society of Washington, lk 13-53.

Hymes, Dell 1974. Foundations in Sociolinguistics: An Ethnographic Approach. Philadelphia: University of Pennsylvania Press.

Isikuankeet = Rahva ja eluruumide loendus 2011. Isikuankeet. http://www.stat.ee/ public/files/aruandevormid/2011/30001140811.pdf?t=1440622576 (17. X 2015).

Jõhvi... = Jõhvi valla statistilised andmed seisuga 31. XII 2011. http://www.johvi. ee/sites/default/files/failid/statistika/statistika_2011_12_31.pdf (17. X 2015). 
Jääts, Indrek 2013. Lugege meid üle! Kagu-Eesti etnoregionalistlikud liikumised ja viimane rahvaloendus. - Akadeemia, nr 6, lk 1076-1110.

J ääts, Indrek 2015. Count us! Ethnic activism in south-eastern Estonia, and the census of 2011. - Journal of Baltic Studies, kd 46, nr 2, lk 243-260.

Kahula... = Kahula 2014. http://entsyklopeedia.ee/artikkel/kahula1 (17. X 2015).

Keda... = Keda loendusel küsitletakse? http://www.stat.ee/56648 (17. X 2015).

Kim, Ronald 2011. Uriel Weinreich and the birth of modern contact linguistics. - Languages in Contact 2010. Toim Piotr P. Chruszczewski, Zdzisław Wąsik. (Philologica Wratislaviensia: Acta et Studia 4.) Wrocław: Philological School of Higher Education in Wrocław Publishing, lk 99-111.

Kokkuvõte... = Kokkuvõte Eesti 2011. aasta rahva ja eluruumide loenduse (REL 2011) käigust. http://www.stat.ee/dokumendid/76666 (17. X 2015).

Ko m m e l, Kutt 2013. Kus elavad meie murderääkijad? - Statistikaameti ajaveeb. https://statistikaamet.wordpress.com/2015/03/13/kus-elavad-meie-murderaaki$\mathrm{jad} /(17 . \mathrm{X} 2015)$.

Koreinik, Kadri, Spiliopoulou Åkermark, Sia, Kühhirt, Eva, Sarhima a, Anneli, Toiva ne n, Reetta 2013. The Võro language in Estonia: ELDIA Case-Specific Report. (Studies in European Language Diversity 23.) MainzWien-Helsinki-Tartu-Mariehamn-Oulu-Maribor: Johannes Gutenberg-Universität.

Ko r e in ik, Kadri, Te n d e r, Tõnu 2014. Eesti keeltest rahvaloendusel. - Emakeele Seltsi aastaraamat 59 (2013). Peatoim Mati Erelt. Tallinn: Teaduste Akadeemia Kirjastus, lk 77-102.

Labov, William 1966. The Social Stratification of English in New York City. Washington, D.C.: Center for Applied Linguistics.

Meillet, Antoine 1904. Comment les mots changent de sens. - L'Année sociologique, nr 9. France: Presses Universitaires de France.

Niedzielski, Nancy A., Prest o n, Dennis R. 2000. Folk Linguistics. New YorkBerlin: Mouton de Gruyter.

Org, Ervin, Reiman, Nele, Uind, Katrin, Velsker, Eva, Pajus alu, Karl 1994. Vastseliina Sute küla elanike murdepruugist ja keelehoiakutest. - Keel ja Kirjandus, nr 4, lk 203-209.

Paju s a lu, Karl 1987. Nivelleeruv murre. Karksi verb. - Keel ja Kirjandus, nr 9, lk 529-543.

Paju s a lu, Karl 1996. Multiple Linguistic Contacts in South Estonian: Variation of Verb Inflection in Karksi. (Publications of the Department of Finnish and General Linguistics of the University of Turku 54.) Turku: Turun yliopisto.

P a r b u s, Ülo 1966. Kirjakeelest, siirdekeelest ja murdekeelest. - Emakeele Seltsi aastaraamat 12 (1966). Tallinn, lk 3-15.

Peipsiääre... = Peipsiääre vald 2012. http://entsyklopeedia.ee/artikkel/peipsiääre_ vald (17. X 2015).

Piirissaare... = Piirissaare vald 2014. http://www.piirissaare.ee/?lang=ee (17. X 2015).

Presto n, Dennis R. 1989. Perceptual Dialectology: Nonlinguists' Views of Areal Linguistics. Dordrecht: Foris Publications.

Presto n, Dennis R. 1999. Introduction. - Handbook of Perceptual Dialectology, Kd 1. Toim Dennis R. Preston. Philadelphia, PA: John Benjamins, lk xxiii-xxxix. S a areste, Andrus 2006 [1952]. Kaunis emakeel. Vesteid eesti keele elust-olust. 
Näiteid eesti keelest ja meelest 1524-1958. Tallinn: Eesti Keele Sihtasutus.

Sjoberg, Örjan, Ta m m ar u, Tiit 1999. Transitional statistics: Internal migra-

tion and urban growth in post-Soviet Estonia. - Europe-Asia Studies, kd 51, nr $5, \mathrm{lk} 821-842$.

$\mathrm{T}$ a $\mathrm{m} \mathrm{m}$ a r $\mathrm{u}$, Tiit 2001. The Soviet Union as a deviant case? Underurbanization in

Soviet Estonia. - Urban Geography, kd 22, nr 6, lk 584-603.

Weber, Max 1968. Economy and Society. Toim Guenther Roth, Claus Wittich.

New York: Bedminister Press.

W i e d e m a n n, Ferdinand Johann 2002 [1864]. Uurimus võru murdest. Tlk Inge

Annom. Toim Külli Habicht, Karl Pajusalu. Tartu: Tartu Ülikooli Kirjastus.

\section{Estonian dialects in the mirror of the last Estonian census}

Keywords: Estonian, dialects, sociolinguistics, ethnodialectology, census

The article addresses the results of the Estonian 2011 population and housing census which was the first census to record Estonian native-speaking residents' self-reported capacities of Estonian dialects. While the census data cannot be perhaps interpreted as the comprehension or regular use of traditional Estonian dialects known from the end of XX century and earlier, the enumeration can still be a valuable source for investigating how the variation of Estonian is perceived in the new Millennium. Informed by perceptual dialectology (Preston 1989, 1999), our main focus is to observe the spread of less prominent dialects which are linguistically closer to Standard Estonian. After reviewing the literature on language shift to common Estonian, we briefly outline some theoretical considerations of sociolinguistics and perceptual dialectology, both of which depart from social constructivist epistemology. Then we map our main findings: firstly, how self-reported capacities of Estonian varieties are geographically spread, and secondly, which (sub)dialects were not reported in the census, and then try to interpret on reasons behind it. Finally, we examine two traditional sub-dialect areas - Lüganuse and Jõhvi - and what particular varieties were reported there.

The analysis revealed that the residents of the peripheries of Estonia (the Western islands and South-East Estonia) marked local dialects more often than the residents of the Northern, Western and central parts of Estonia. Besides migration, the spread of the well known dialects with a strong and perhaps cultivated identity can be described by the radiation effect (see Fought 2002), which explains the expansion of prominent dialects from their traditional areas into other parts of the country, in some rare cases dominating other dialects almost entirely. That is especially the case of the Võru dialect but also of the island dialect that radiated across the sea to the inland parishes. Part of it has to do with people themselves moving but it may very well be that dialects with more dominant identities tend to suppress the awareness of other nearby dialects. All in all, dialect differences are as real as people believe them to be and these beliefs may have a great impact on the present and future of dialects. People may endorse the use of local dialects or abandon them entirely. 
Siim Antso (b. 1990), MA, University of Tartu, Institute of Estonian and General Linguistics, Specialist of Geolinguistics, siim.antso@ut.ee

Kadri Koreinik (b. 1970), PhD, University of Tartu, Institute of Estonian and General Linguistics, Senior Research Fellow, kadri.koreinik@ut.ee

Karl Pajusalu (b. 1963), PhD, University of Tartu, Institute of Estonian and General Linguistics, Professor of the History of the Estonian Language and Estonian Dialects, karl.pajusalu@ut.ee 